\title{
ARCHAEOLOGICAL PROSPECTION IN SOUTHEASTERN PARÁ STATE, BRAZIL USING GEOPHYSICAL METHODS: A CASE STUDY OF SÍTIO DOMINGOS
}

\author{
José Gouvêa Luiz ${ }^{1}$ and Edithe da Silva Pereira²
}

\begin{abstract}
Magnetic, resistivity and ground-penetrating radar (GPR) methods were applied to Sítio Domingos, a Brazilian archaeological site located in Pará State, to find objects buried by an ancient civilization that may have inhabited the site. Archaeological excavations based on the locations of magnetic anomalies reveal a concentration of ceramic fragments and pots. The correlation between the resistivity models and the soil profile of the study area suggests that the resistivity range of 2000 to 2500 ohm-m represents the archaeological occupation layer. Several anomalous features detected by GPR are correlated with magnetic anomalies. However, when these features are analyzed independently of the magnetic anomalies, they do not conclusively represent the objects being searched. Therefore, GPR is not recommended as the main tool for archaeological prospection in the study area.
\end{abstract}

Keywords: magnetometry, electrical resistivity, GPR, archaeological excavation.

RESUMO. Os métodos magnético, resistividade e radar de penetração no solo (GPR) foram aplicados no Sítio Domingos, um sítio arqueológico brasileiro localizado no Estado do Pará, para encontrar objetos enterrados por uma civilização antiga que pode ter habitado a região. Escavações arqueológicas com base nos locais de anomalias magnéticas revelaram uma concentração de fragmentos de cerâmica e vasos. A correlação entre os modelos de resistividade e do perfil do solo da área de estudo sugere que a faixa de resistividade de 2000-2500 ohm-m representa a camada de ocupação arqueológica. Várias feições anômalas detectadas pelo GPR são correlacionáveis com anomalias magnéticas. No entanto, quando essas feições são analisadas independente das anomalias magnéticas, elas não representam de forma conclusiva os objetos que estão sendo procurados. Portanto, o GPR não é recomendado como a principal ferramenta de prospecção arqueológica na área de estudo.

Palavras-chave: magnetometria, resistividade elétrica, GPR, escavação arqueológica.

\footnotetext{
1Programa de Pós-Graduação em Geofísica, UFPA, Caixa Postal 8608, 66075-970 Belém, PA, Brazil. Phone: +55(91) 3201-7692; Fax: +55(91) 3201-7693 - E-mail: gouvea@ufpa.br

2 Museu Paraense Emílio Goeldi, Av. Perimetral, 1901, 66077-530 Belém, PA, Brazil. Phone: +55(91) 3217-6047 - E-mail: edithepereira@museu-goeldi.br
} 


\section{INTRODUCTION}

The use of Geophysics to assist in archaeological prospecting is relatively recent. Although the first works date back to the mid1940s (Aitken, 1974), only since the 1980s they have become very common because of the development of geophysical techniques to study in detail the first $50 \mathrm{~m}$ of the crust, mainly to solve Engineering issues and problems related to environmental contamination. Electrical resistivity were the first geophysical measurements used in archaeological prospecting, dating from 1946 (Aitken, 1974); following (1958), magnetic measurements began to be used (Wynn, 1986a). Today, the main geophysical methods applied in archeology are resistivity (resistivity measurements), electromagnetic (measurements of electrical conductivity and magnetic susceptibility), magnetic (measures of the Earth's magnetic field) and ground penetrating radar or GPR (measures of the propagation of electromagnetic wave). A review of the history of the application of geophysical methods in archeology is presented by Wynn (1986a).

Application of Geophysics in Archaeology allows the detection of the following materials, important for the archaeological study: ceramic (pots, urns, sherds), ovens, campfires, floors, foundations of buildings and tunnels. Geophysics can also provide information on the subsurface stratigraphy and layer occupation.

In the environment of archaeological prospection, the magnetic anomalies can be caused by intense heating of the ground produced by ovens and campfires, soil disturbance and the burial of objects, among which stand out in the Amazon Region, pots, ceramic fragments, urns and organic matter. Campfires maintained on soil create a reducing environment that favors the formation of magnetite (main mineral responsible for magnetization of geological materials) when moderate amounts of iron are present in the soil (Wynn, 1986b; Schmidt, 2007). Moreover, the soil disturbed by burials often become locally oxidizing, creating an environment which destroys the present magnetization (Wynn, 1986b) or can transform the magnetite in maghemite, a mineral somewhat less magnetic (Schmidt, 2007). Also, the decomposition of organic matter, buried in the soil during human occupation, can produce anaerobic bacteria that are able to transform the mineral hematite (nonmagnetic) in magnetite (Schmidt, 2007).

Archaeological features as soil occupation, urns and buried pipelines, foundations of buildings and tunnels produce patterns in the records of GPR that can be distinguished from patterns associated with the material naturally deposited during geological processes. Among these patterns stand out the discontinuities in the records, usually caused by turning over the soil during the burials, and hyperbolic forms, which can be caused by urns, pipelines and foundations of buildings.

In Brazil, the first experiments of geophysics to Archaeology were magnetic and electrical resistivity measurements, conducted in 1977 in Pará, Amazon Region, by Dr. José Seixas Lourenço and his graduate student at the time, José Jerônimo de Alencar Alves (Barradas et al., 1999). Since then, geophysical prospection has been successfully used to assist in the identification of potential archaeological excavation targets in the state of Pará, (Alves, 1979; Alves \& Lourenço, 1981; Roosevelt, 1991; Barradas et al., 1999; Bevan \& Roosevelt, 2003; Aragão et al., 2010; Luiz, 2010). The remains found in excavations conducted in the Amazon Region are mainly ceramic (sherds, pots, burial urns), charcoal and lithics left by ancient indigenous communities. In general they are found in a layer of black soil known as Indian Black Earth (IBE), Archaeological Black Earth (ABE) or Amazonian Dark Earth (ADE). Analysis of ADE samples have demonstrated that such soils present high levels of chemical nutrients, high $\mathrm{pH}$ and large amounts of organic material, making it very fertile (Kern \& Kampf, 1989; Costa \& Kern, 1999; Kern et al., 2003; Glaser \& Woods, 2004). These soils probably result from degradation of organic debris associated with ancient human occupation and disposal activities (Schaan et al., 2009). The ADE also exhibit lower clay and are more structured than the surrounding soils, making them more electrically resistive as evidenced by Roosevelt (2007).

This paper describes a geophysical survey performed at Sítio Domingos (PA-AT-247: Domingos), which was discovered in 2000 by archaeologists from the Museu Paraense Emílio Goeldi during a survey of an area that would be affected by the future mining of copper ore (Magalhães, 2001). The site is located at approximately $06^{\circ} 26.39^{\prime} \mathrm{S}, 50^{\circ} 01.95^{\prime} \mathrm{W}$ (UTM: $22606981 \mathrm{E}$, 9288074 N) in the municipality of Canaã dos Carajás, southeast of the state of Pará (Fig. 1).

Archaeological excavations conducted prior to the geophysical survey by archeologists from the Museu Paraense Emílio Goeldi allowed the recovery of many ceramic fragments and three intact ceramic vessels, one of which is a burial urn. This geophysical survey was performed with the goal of detecting anomalies related to ceramic artifacts buried at the site, assisting the archaeological prospection identify potential locations for new excavations, and to map the ADE.

The survey consisted of measurements of the earth's magnetic field, apparent electrical resistivity and the propagation of electromagnetic waves at a frequency of $400 \mathrm{MHz}$ with groundpenetrating radar (GPR). 


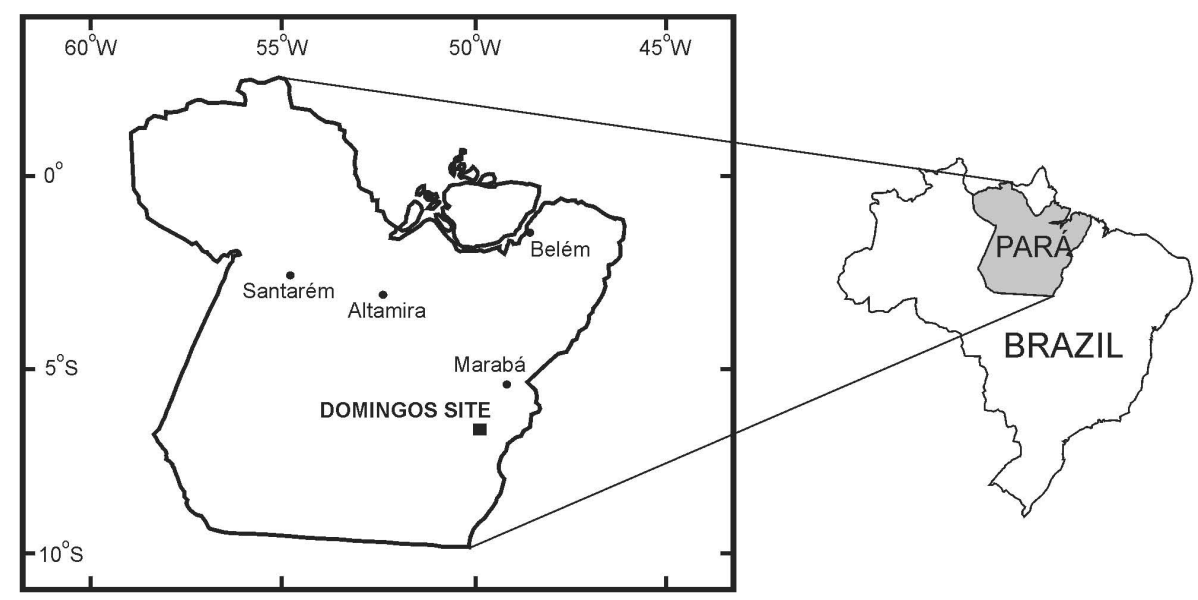

Figure 1 - Map of the geophysical survey area.

Measurements were performed in three field campaigns: October 4 to 8, 2003, June 10 to 17, 2004 and July 27 to 30, 2004. The first campaign consisted of magnetic and apparent electrical resistivity measurements over a $30 \mathrm{~m} \times 50 \mathrm{~m}$ area in the western portion of the site (Fig. 2). In the second campaign, GPR measurements were taken in the eastern portion, covering $40 \mathrm{~m}$ $\times 60 \mathrm{~m}$ (Fig. 2), and magnetic measurements of the same area were taken in the third campaign.

\section{MATERIAL AND METHODS}

\section{Magnetic measurements}

The magnetic measurements at Sítio Domingos were performed at intervals of $1 \mathrm{~m}$ along profiles spaced at $2 \mathrm{~m}$ and oriented in the direction $\mathrm{N} 340^{\circ}$.

The profiles are numbered from west to east, starting from 10 and ending at $80(10,12,14, \ldots, 78,80)$. Profile 40 coincides with one of the baselines established by the archaeological research team. The measuring stations are numbered from south to north, starting from 0 and ending at 50 in the western portion of the study area and ending at 60 in the eastern portion. In all profiles, station 30 coincides with a second baseline that is perpendicular to the profile 40 baseline.

In the first campaign, the magnetometer sensor was fixed $0.5 \mathrm{~m}$ above the ground surface. In the third campaign, the magnetic measurements were performed with the sensor placed on the ground surface, with its axis perpendicular to the measurement profiles. This was necessary to prevent interference from a high-voltage power line perpendicular to the profiles, located approximately $150 \mathrm{~m}$ from the survey area; this line had not been active during the first campaign.
The diurnal variation of the magnetic field was monitored by the periodic occupation of a reference station (base station) at time intervals of less than 40 minutes. Station 30 of profile 40 (the intersection of the two baselines established by the archaeological research team) is used as the reference station. Each measurement was corrected for the diurnal variation of the magnetic field, assuming a linear trend in magnetic field between measurements at the reference station.

\section{Measurements of apparent electrical resistivity}

Apparent electrical resistivity measurements were carried out along the same profiles as the magnetic surveys in the first field campaign, but at intervals of $4 \mathrm{~m}$ starting from profile 10 . Thus, profiles 10, 14, 18, 22, 26, 30, 34,38 and 40 were surveyed. The electrodes were arranged in a dipole-dipole configuration, and the separation between electrodes was $1 \mathrm{~m}$, with 5 sampling levels.

The objective of the survey was to determine the relationship between the resistivities and the shallow subsurface sediments to map the archaeological occupation layer or archaeological black earth (ABE).

\section{GPR measurements}

The GPR measurements were only conducted in the area surveyed in the second field campaign, the same as the magnetic survey in the third field campaign (the eastern portion of the study area). Thus, GPR measurements were taken between stations 0 and 60, from lines 42 to 80 .

A GSSI SIR 3000 with $400 \mathrm{MHz}$ antennas was used for the measurements. The data were collected in time mode, with the antennas continuously moving on the ground surface. The hori- 


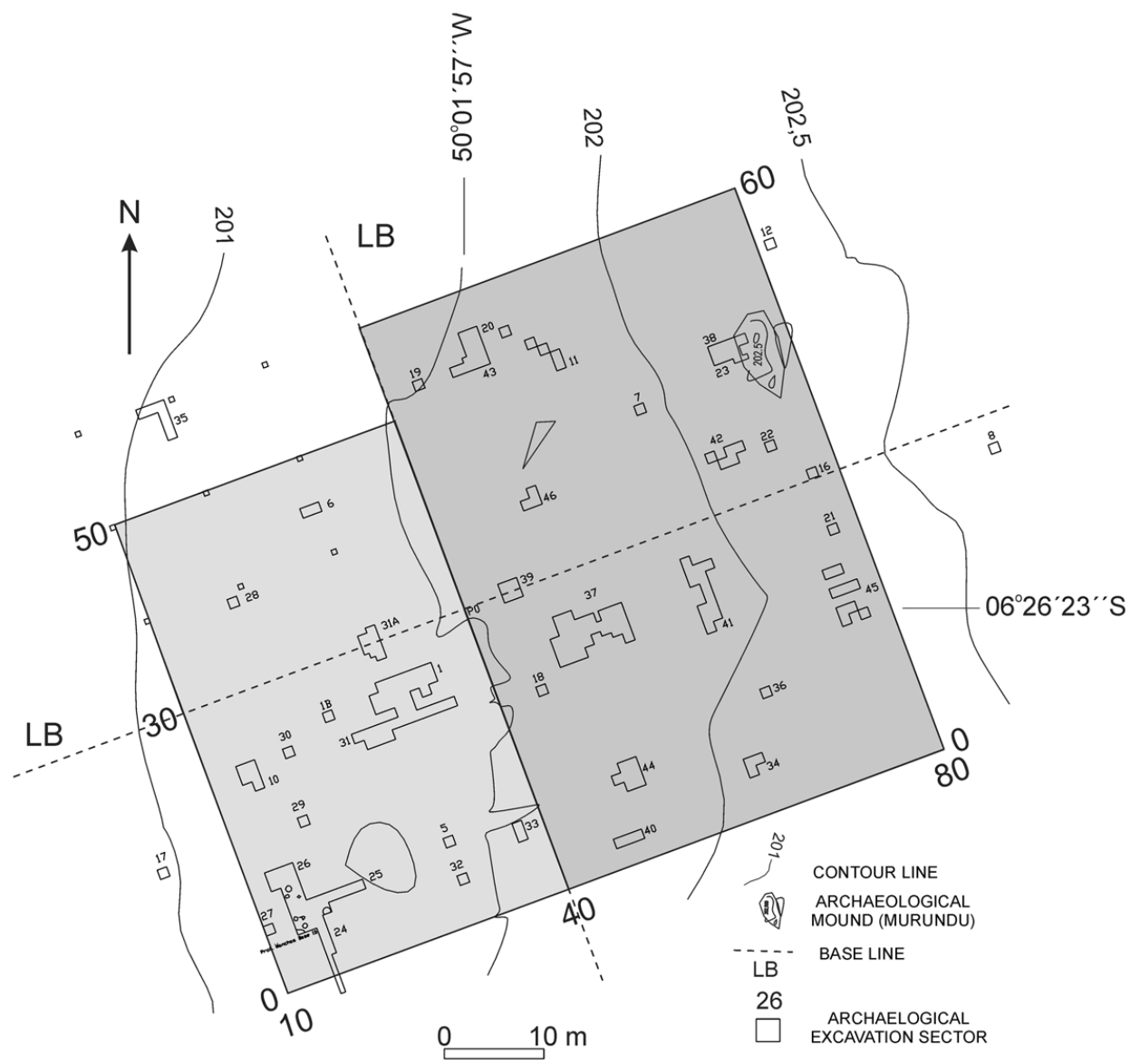

Figure 2 - Areas of geophysical surveys with the locations of excavations.

zontal distance in the profiles was controlled by inserting marks into the record at $5 \mathrm{~m}$ intervals.

The objective of the survey was to detect anomalous features such as (a) discontinuities in reflectors (layers) that may indicate burials or (b) small gap hyperboles that can indicate the presence of compacted three-dimensional objects, such as ceramic urns.

\section{RESULTS IN THE WESTERN HALF OF THE STUDY AREA Magnetic method}

The magnetic measurements performed in the western portion of the study area are shown in Figures 3 and 4. The field values are given relative to the value $25,845 \mathrm{nT}$ measured at the reference station (station 30 of profile 40 ).

Figure 3 shows an anomalous region near the southwestern corner of the map, in the area bound by profiles 10 to 20 and stations 0 to 13. This area contains the largest measured field variation (-343 to $345 \mathrm{nT}$ ), which is very large when compared to the less than $100 \mathrm{nT}$ magnetic anomalies often associated with ceramic objects.
The $50 \mathrm{nT}$ contour interval used in Figure 3 is relatively high and can hide weaker anomalies, such as those normally expected for ceramic material. Therefore, we discarded the high values not coherent with the values measured in other parts of the area to eliminate the strong anomaly in the southwestern corner and reduced the contour interval; the resulting map is shown in Figure 4

Figure 4 shows additional lower-intensity anomalies that are more compatible with ceramic material. These anomalies are centered in the following locations: profile 18, station 16; profile 18, stations 22 to 24; profiles 18 and 20, station 38; profile 22, station 2; profile 28, stations 2 and 21; profile 30, station 3; and profile 38 , stations 6 and 8 .

\section{Electrical resistivity method}

We correlated the electrical resistivity measurements to the lithological profile described in the archaeological excavations to find a relationship between the resistivities obtained in interpretative models and the occupation layer. The description of the sedi- 


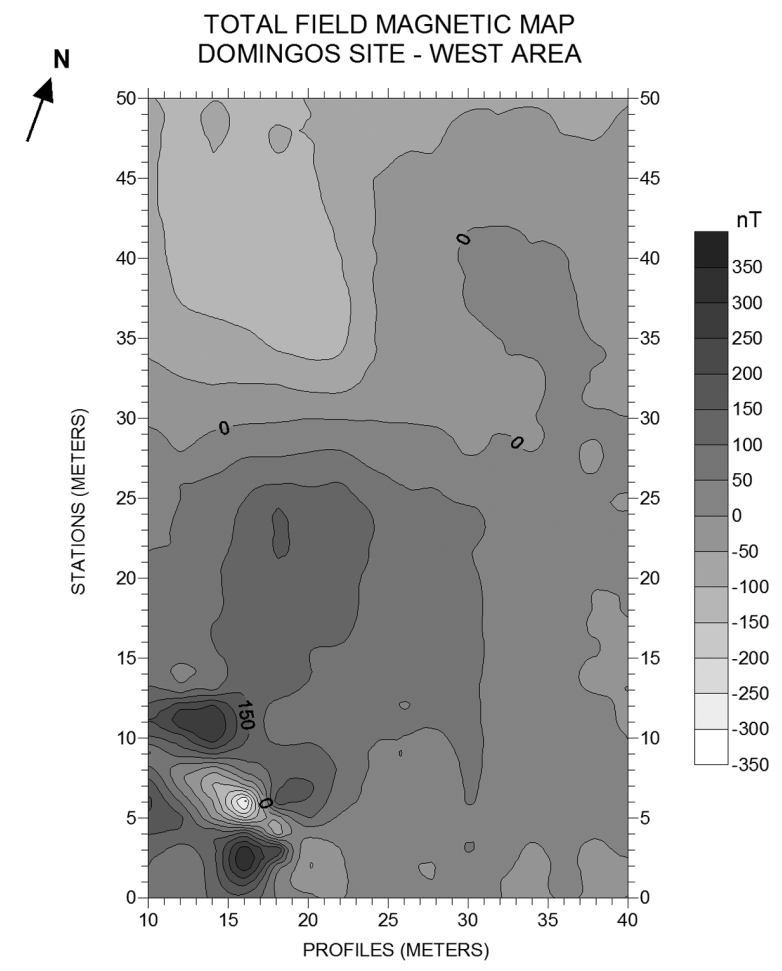

Figure 3 - Magnetic map of the western half of the area. The values are relative to the value $25,845 \mathrm{nT}$ measured at station 30 of profile 40 .

ments from earlier excavations of the Sítio Domingos area, performed by the archaeological research team of the Museu Goeldi, allowed the establishment of the following lithological profile for the area, which serves as a reference for the interpretation of resistivity measurements. From top to bottom:

- Layer 1, level A - Loose soil, sandy, with decaying leaves and roots. This layer has a thickness between 0.02 and $0.05 \mathrm{~m}$ and is called the organic mantle.

- Layer 1, level B - Dark gray soil, gently compacted, dry, sandy, fine-grained, with roots. Its thickness typically varies from 0 to $0.10 \mathrm{~m}$.

- Layer 1, level C - Very dark grayish-brown soil, compact, hard, dry, sandy, fine to medium grained, with a thickness between 0.20 and $0.40 \mathrm{~m}$. Many archaeological remains, particularly ceramic fragments, were found in this layer.

- Layer 1, level D - Dark grayish-brown soil, loose to compacted, sandy, fine to medium grained, dry to moist, with a thickness between 0.05 and $0.20 \mathrm{~m}$. This level represents the transition to layer 2.

- Layer 2 - Light gray soil, loose to slightly compacted, dry to moist, sandy, fine to coarse grained, may contain

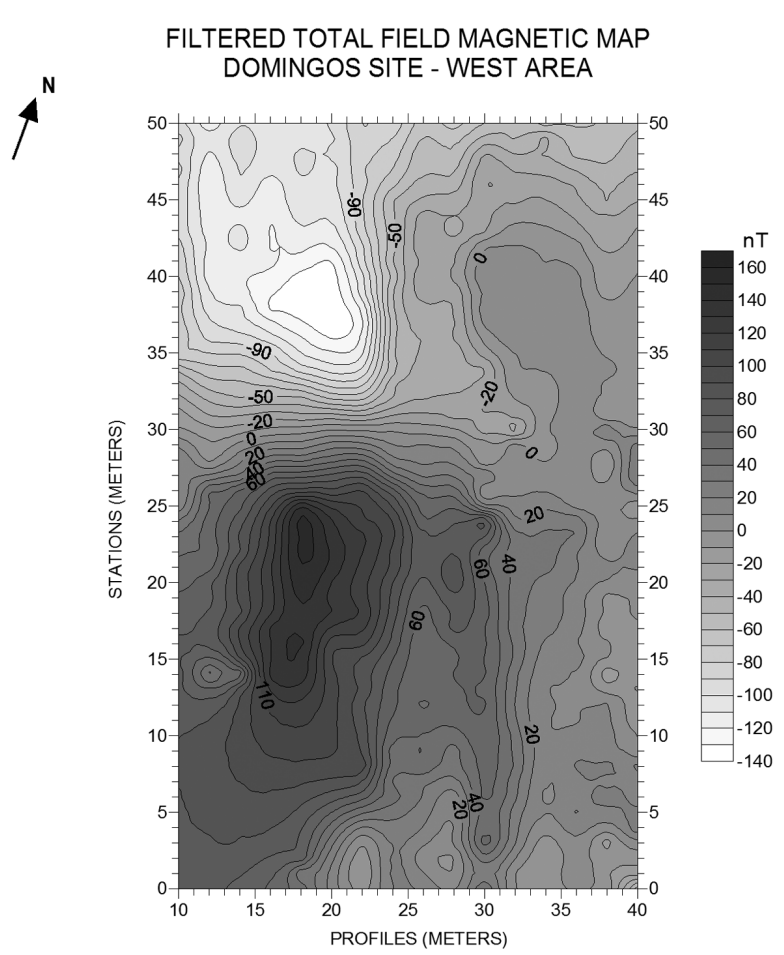

Figure 4 - Filtered magnetic map of the western half of the area. The values are relative to the value $25,845 \mathrm{nT}$ measured at station 30 of profile 40 .

gravel and ferruginous concretions. It is usually more than $0.20 \mathrm{~m}$ thick.

Layer 1, constitutes the ADE or archaeological occupation layer. Layers 1 and 2 can be seen in Figure 5 .

The resistivities measured are correlated with the lithology observed in archaeological excavations of the study area prior to the geophysical survey. This correlation indicates the following: (a) the resistivity measurements were affected by the sediments observed in the excavations and those below them (the investigation depth in excavations was typically shallower than $0.70 \mathrm{~m}$, while the resistivity measurements reached a depth of $1.7 \mathrm{~m}$ ); (b) the resistivity measurements are not able to resolve the small thicknesses of the levels in layer 1 described by the archeology (some on the order of $0.10 \mathrm{~m}$ thick); and (c) the resistivities essentially reflect the moisture and compaction of the sediments identified.

In Figures 6 to 8, some of the resistivity data are shown as profiles. The upper portions of the figures show pseudo-sections of the apparent resistivities measured in each profile, and the middle portions show pseudo-sections of the apparent resistivities calculated for the resistivity model shown in the lower portions of the figures. In each profile, the similarity between the 


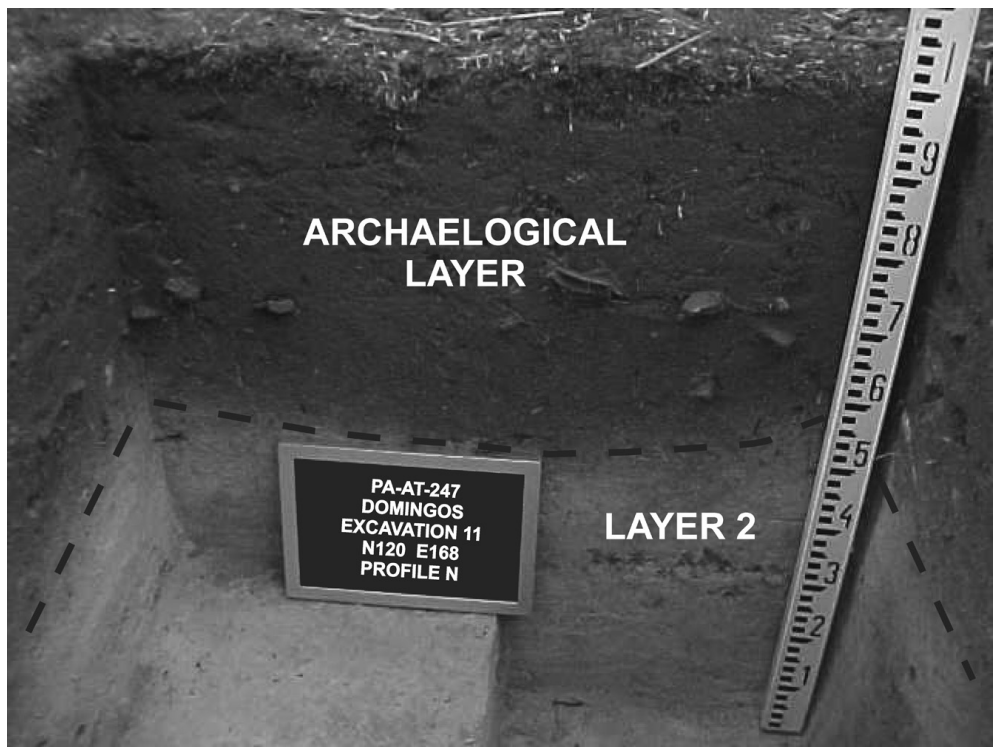

Figure 5 - Excavation showing the archaeological layer and layer 2.

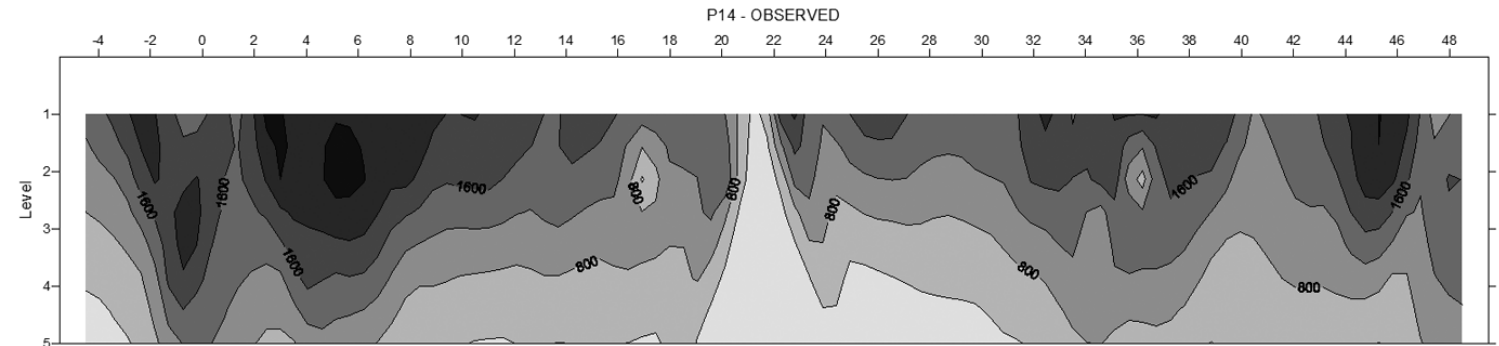

P14 - CALCULATED

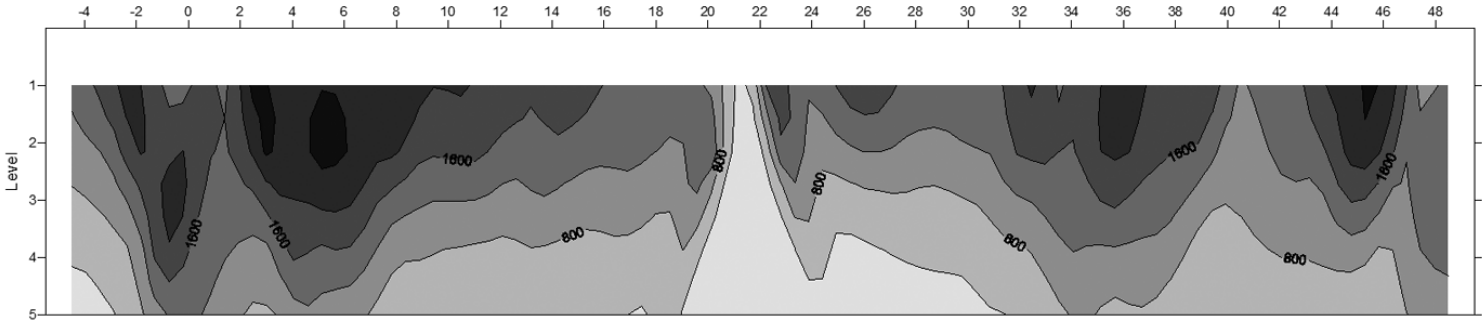

P14 - RESISTIVITY MODEL (Absolute error $=5.2 \%$ )

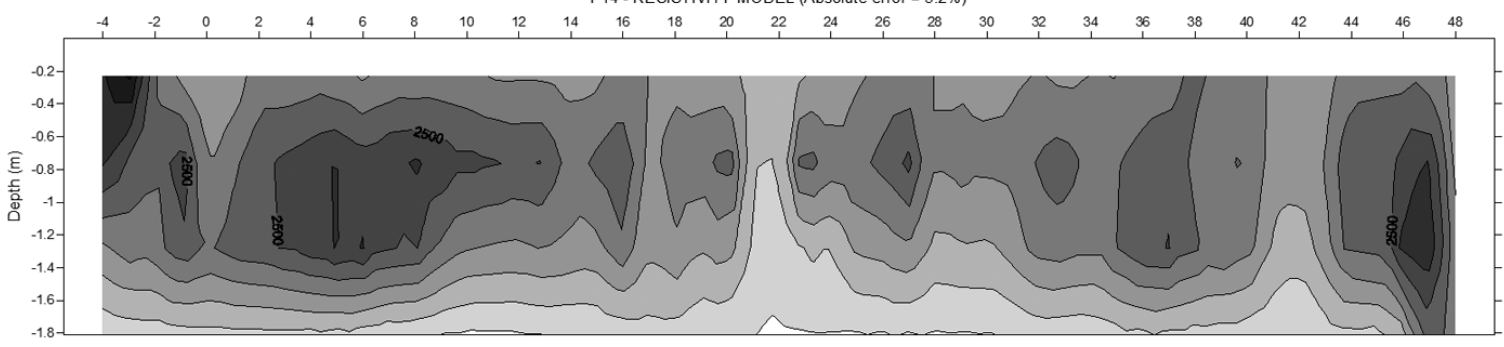

Figure 6 - Profile 14 resistivity: measured, calculated and modeled. 


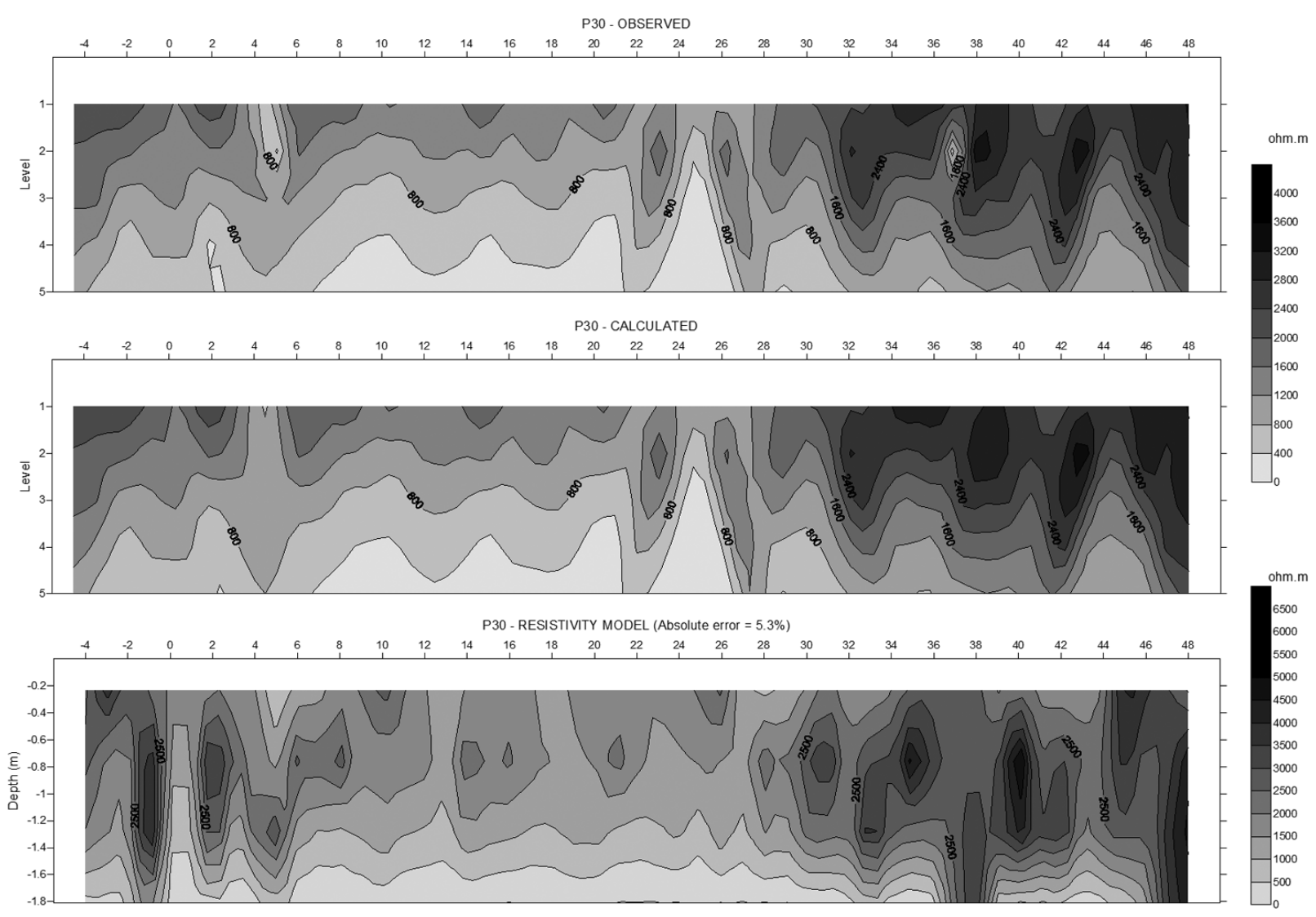

Figure 7 - Profile 30 resistivity: measured, calculated and modeled.

pseudo-sections of the measured and modeled values demonstrate if the model gives an acceptable resistivity distribution to the subsurface. In the inversion of data to obtain the resistivity models, five iterations were completed, and the maximum error between the calculated and measured values was $6.6 \%$, obtained for the inversion of profile 34 (Fig. 8).

The profiles of the resistivity models (Figs. 6 to 8 ) show interpreted sections of the subsurface for depths between 0.3 and $1.7 \mathrm{~m}$. Levels $\mathrm{A}$ and $\mathrm{B}$ of the archaeological layer are very thin (less than $0.10 \mathrm{~m}$ ) and are difficult to distinguish in the resistivity profiles.

The top of level $C$ is generally defined from the depth of $0.10 \mathrm{~m}$ and its thickness varies from 0.20 to $0.40 \mathrm{~m}$. Level $\mathrm{D}$ (below level 1C), which has similar lithological characteristics, varies from 0.05 to $0.20 \mathrm{~m}$ in thickness. When correlated to the resistivity models, the thicknesses and lithological characteristics (dry sandy soil) of the four levels, suggest that values between 2000 and 2500 ohm-m can be associated with the ADE.

Profiles 14, 30 and 34 cross some of the archaeological excavations performed in the area. For example, profile 14 (Fig. 6) cuts excavation 10 at a position of $21 \mathrm{~m}$, where level $\mathrm{C}$ of the archaeological layer contains ceramic fragments. In this excavation, the thickness of level $C$ varies from 0.05 to $0.37 \mathrm{~m}$ and shows a strong arching in its north wall, where the top of this layer is $0.05 \mathrm{~m}$ below the ground surface and the layer is $0.05 \mathrm{~m}$ thick. The resistivity model at this location can be associated with the material described in the excavation and is compatible with the identified arching.

In profile 14 (Fig. 6), there are several other locations where the modeled resistivities have values that can be associated with the archaeological layer, including a strong anomalous magnetic zone between positions 9 and $12 \mathrm{~m}$, in the southwest portion of the magnetic map in Figure 3.

Profile 30 (Fig. 7) cuts excavations 1 (at position $26 \mathrm{~m}$ ) and 6 (at position $46 \mathrm{~m}$ ). In excavation 1, level $\mathrm{C}$ of the archaeological layer varies from 0.15 to $0.30 \mathrm{~m}$ in thickness and its top is at 0.08 to $0.17 \mathrm{~m}$ depth. In this excavation, level $\mathrm{D}$ occurs immediately below level $\mathrm{C}$ and is moist, while layer 2 contains clay. Both the moisture and clay cause a decrease in resistivity. Therefore, the resistivity model has lower resistivities in this area than 


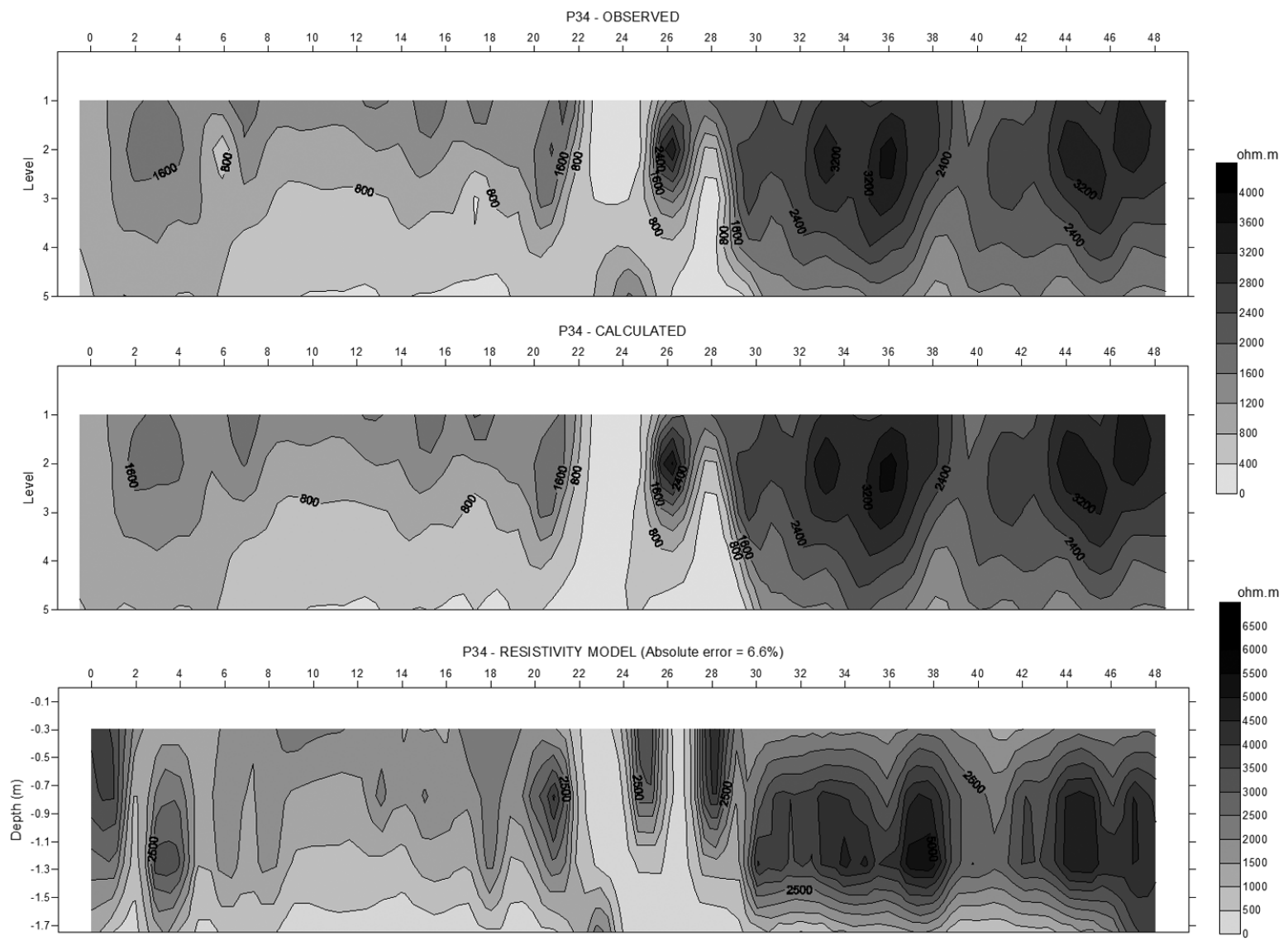

Figure 8 - Profile 34 resistivity: measured, calculated and modeled.

those typically associated with this archaeological layer. This layer contributed little to the measurements, most likely due to its small thickness and proximity to the ground surface. The resistivities decrease further with increasing depth at this location, suggesting that a clayey/moist material is below layer 2. In excavation 6, the archaeological layer has an approximately uniform thickness of $0.30 \mathrm{~m}$, as seen in the resistivity model of Figure 7 .

The resistivities associated with the archaeological layer (2000 to 2500 ohm-m) at depths of 0.3 and $0.7 \mathrm{~m}$ are shown in Figures 9 and 10, which give the probable distribution of the archaeological layer based on the resistivities.

Archaeological Excavations in the Western Portion of the Study Area Archaeological excavations were conducted before and after the geophysical survey. Those after the geophysical survey were conducted to test the observed magnetic anomalies. The locations of excavations conducted before and after the geophysical survey are shown in Figure 2.

In the excavations conducted before the geophysical survey, intact ceramic vessels (including a burial urn) and a large number of ceramic fragments were found. In Figure 11, one can see the burial urn found in excavation 6, and in Figure. 12, a large number of ceramic fragments found in excavation 10 can be observed. Ceramic fragments found in excavation 10 were dated by thermoluminescence producing ages between $170 \pm 12$ and $1010 \pm 130$ AD.

The magnetic anomalies were investigated by conducting 10 excavations, which produced many ceramic fragments and some polished ax blades. In the strong anomalous magnetic zone (southwestern corner of the map in Fig. 3), a large amount of ceramic material was found, as well as mafic rocks that are rich in magnetic minerals (most likely magnetite). These rocks are the presumed source of the observed strong magnetic anomaly. Figures 13 and 14 show pictures of excavation 26, conducted at the site of this anomaly. Ceramic fragments can be observed in Figure 13, and Figure 14 shows the blocks of magnetic rock below the level containing pottery. Charcoal found in this excavation was dated by Carbon-14 indicating age of $1010 \pm 40 \mathrm{AD}$.

Datings performed on other materials collected in excavations show the following ages: $320 \pm 40$ and $1590 \pm 140 \mathrm{AD}$ (thermoluminescence in ceramic of excavation 11), $790 \pm 40 \mathrm{AD}$ 
2000 - 2500 OHM.M RESISTIVITY, DEPTH $0.3 \mathrm{~m}$ DOMINGOS SITE - WEST AREA

\section{$4^{N}$}

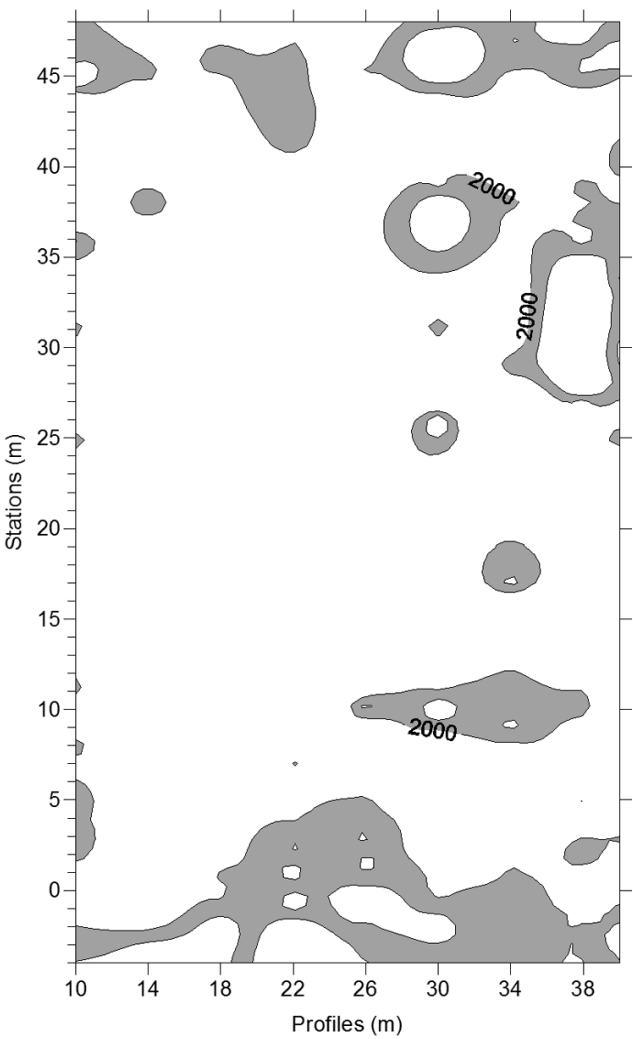

Figure 9 - Distribution of the resistivity range 2000-2500 ohm-m in the western area at $0.3 \mathrm{~m}$ depth.

(Carbon-14 in charcoal of excavation 25) and $840 \pm 60 \mathrm{AD}$ (Carbon-14 in charcoal of excavation 32).

\section{RESULTS IN THE EASTERN HALF OF THE STUDY AREA Magnetic method}

The magnetic measurements conducted in the eastern half of the study area are shown in Figure 15. The magnetic field values, as before, are given relative to the value $25,845 \mathrm{nT}$ measured at the reference station (station 30 of profile 40 ).

Figure 15 shows several magnetic anomalies, some of which have very high amplitudes (greater than $300 \mathrm{nT}$ ), such as those in profile 58 (station 57), profile 70 (station 35) and profile 74 (stations 44 to 45). In comparison the magnetic anomalies in the western portion of the study area (Figs. 3 and 4), those in the eastern portion are much more localized and limited to only one station.

Although there are many magnetic anomalies in the eastern part of the study area, we consider only those that correspond to
2000 - 2500 OHM.M RESISTIVITY, DEPTH 0.7 m DOMINGOS SITE - WEST AREA

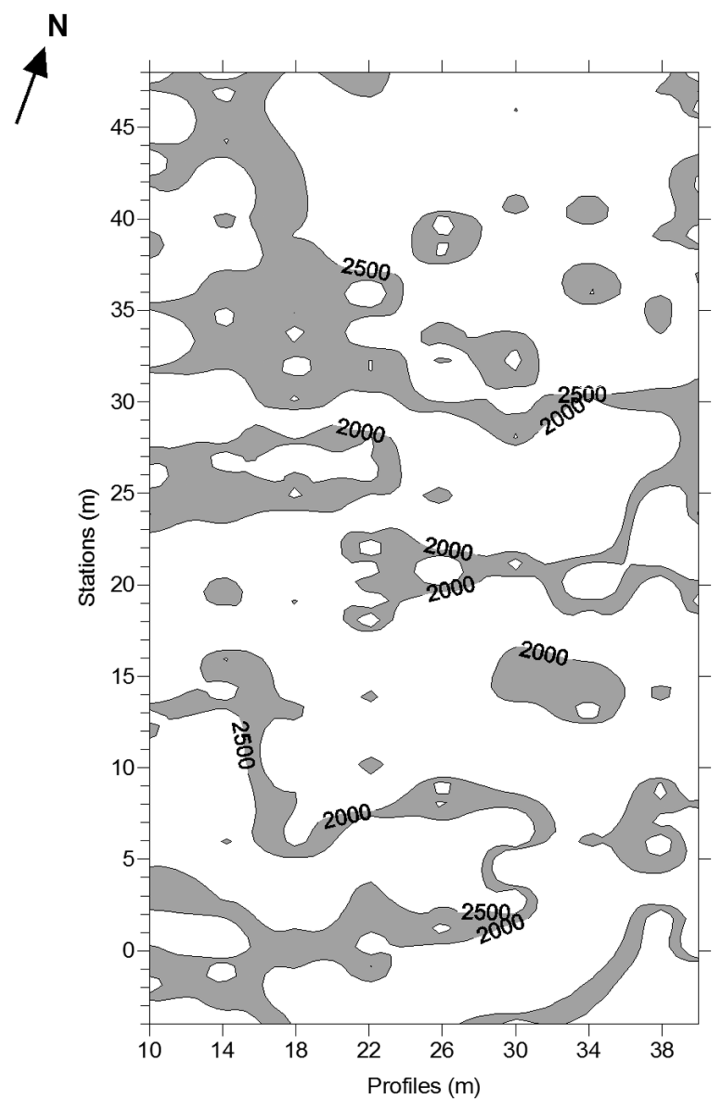

Figure 10 - Distribution of the resistivity range 2000-2500 ohm-m in the western area at $0.7 \mathrm{~m}$ depth.

anomalous features from the GPR survey for archaeological excavation. These anomalies are located at the following positions: profile 46, station 2; profile 48, stations 22 and 23; profile 54, station 22; profile 56 , stations 24,46 and 52 ; profile 58 , station 13; profile 62, station 36; profile 64, stations 19 to 26; profile 70 , station 35; profile 74, stations 44, 45 and 59; profile 76, stations 16 and 18; and profile 78, stations 16 and 18.

\section{GPR method}

The GPR data were processed with the aid of the computer program Reflexw. Processing involved the following steps:

(a) the spatial redistribution of sampling to obtain a uniform spacing between measurements;

(b) the application of a low-pass filter (dewow);

(c) the establishment of zero record time to obtain the ground surface position; 


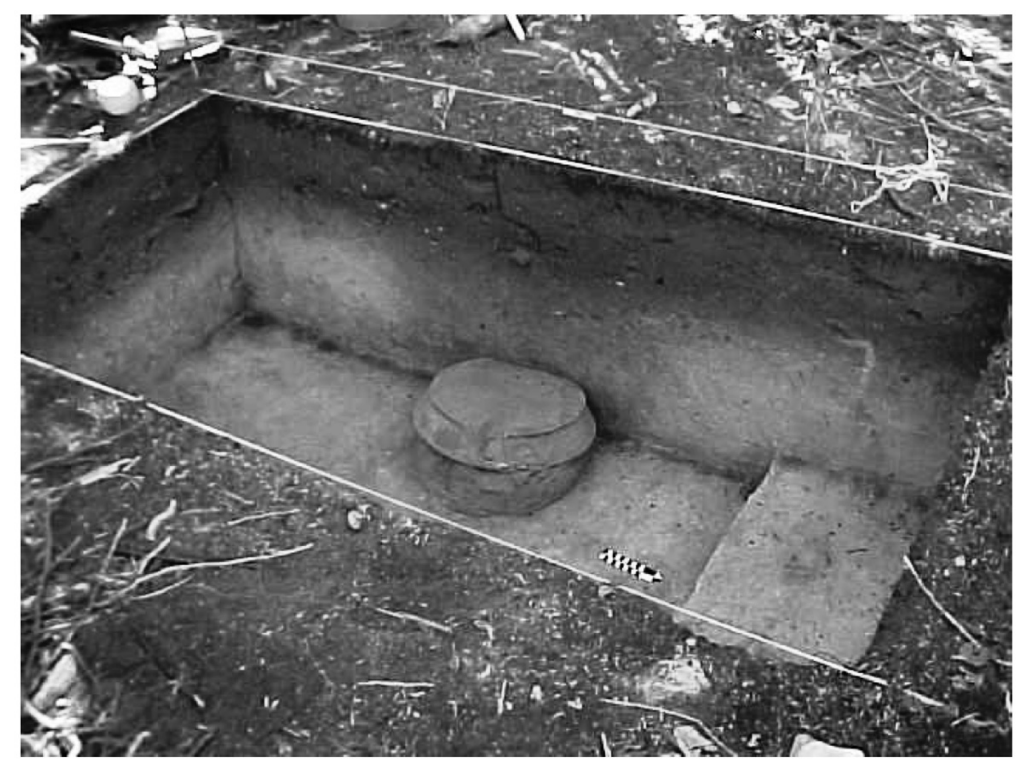

Figure 11 - Burial urn found in excavation 6, conducted before the geophysical survey.

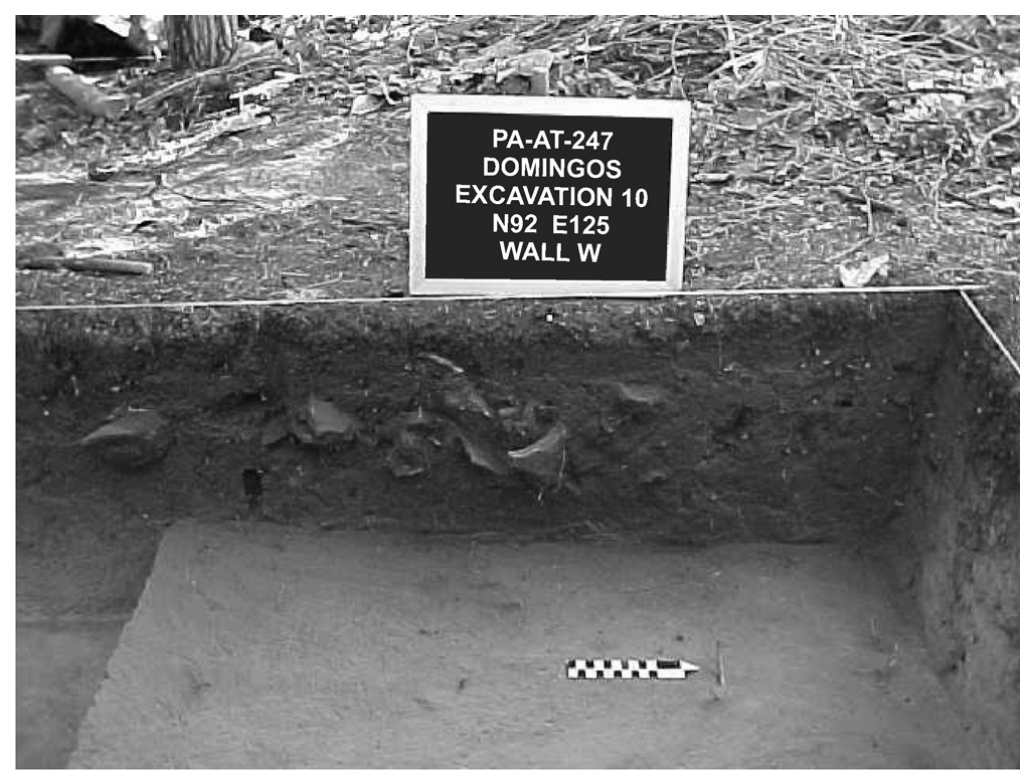

Figure 12 - Ceramic fragments found in excavation 10, conducted before the geophysical survey.

(d) the determination of the speed of electromagnetic wave propagation using hyperbola superposition;

(e) band-pass filtering with cutoff frequencies of 200 and $800 \mathrm{MHz}$;

(f) gain application;

(g) background removal; and

(h) the application of a moving average filter.
In all profiles, the vertical time scale was converted into depth using a wavespeed of $0.1 \mathrm{~m} / \mathrm{ns}$, which was obtained from the superposition of hyperbola in Reflexw.

The radargrams contain anomalous features such as hyperbolic records and gaps in the records, which appear as lateral discontinuities. The hyperbolic shapes are typically caused by two- or three-dimensional bodies, which may be boulders, channels or, in archaeological prospection, ceramic pots. The discontinuities may be due to disruptions in the normal layering of 


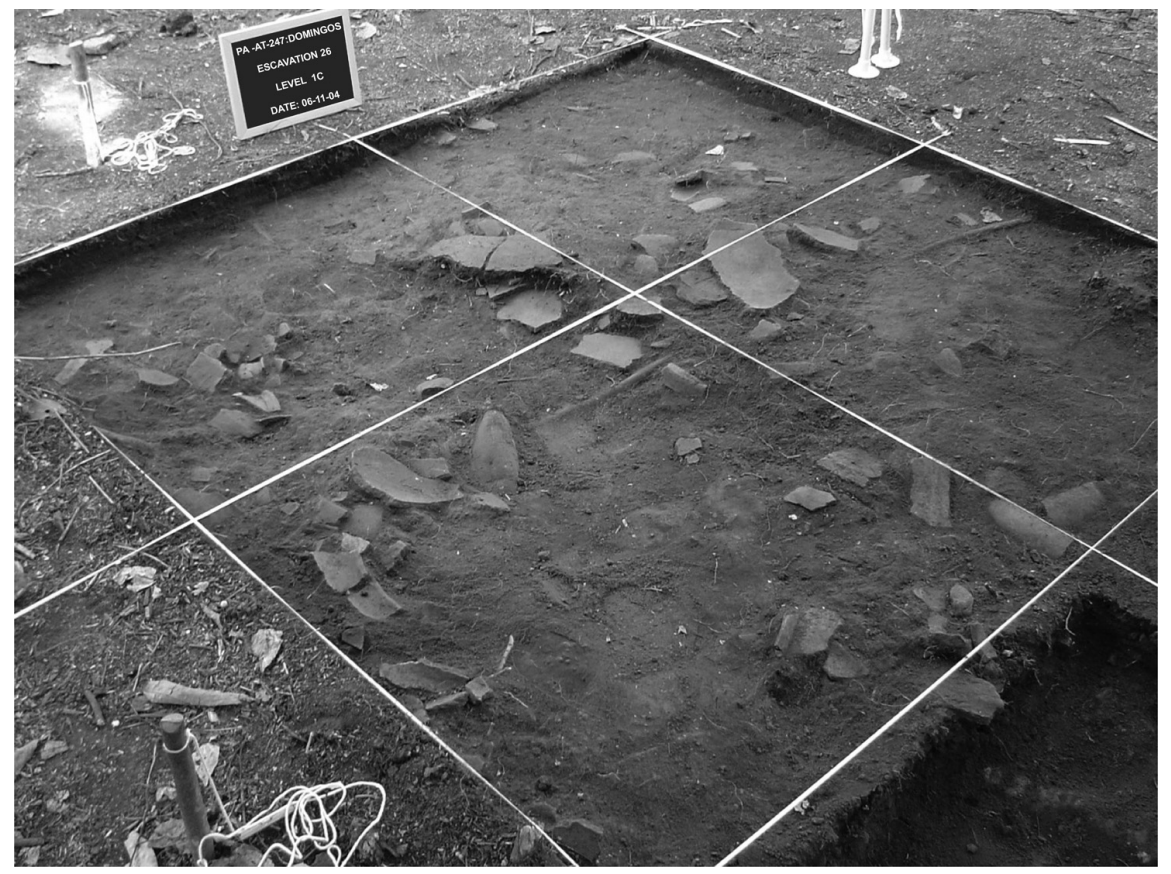

Figure 13 - Excavation 26, conducted over the strong magnetic anomaly in the southwest of the western half of the area, showing ceramic fragments.

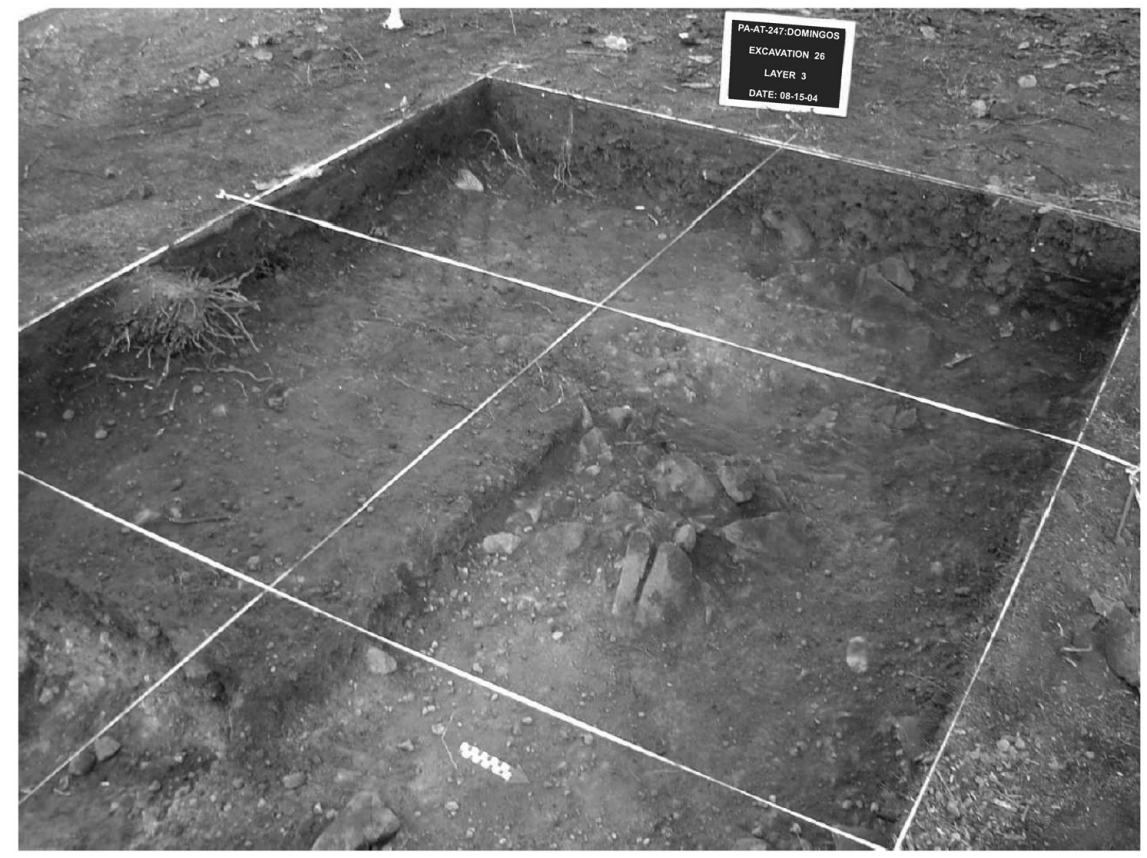

Figure 14 - Excavation 26, conducted over the strong magnetic anomaly in the southwest of the western half of the area, showing blocks of rocks rich in magnetic minerals.

sediments, which can be caused by burials. However, excavations in this area have shown that many of these hyperbolic features are caused by roots or rocks.

Some of the anomalous features in the radargrams occur along or near magnetic anomalies. These locations, which were described earlier, were recommended for archaeological excavation. Figures 16 to 19 show the radargrams obtained for profiles 48, 54, 76 and 78, where the features associated with the magnetic anomalies are highlighted. Buried ceramic artifacts were found in these sites (Figs. 20 to 23). 


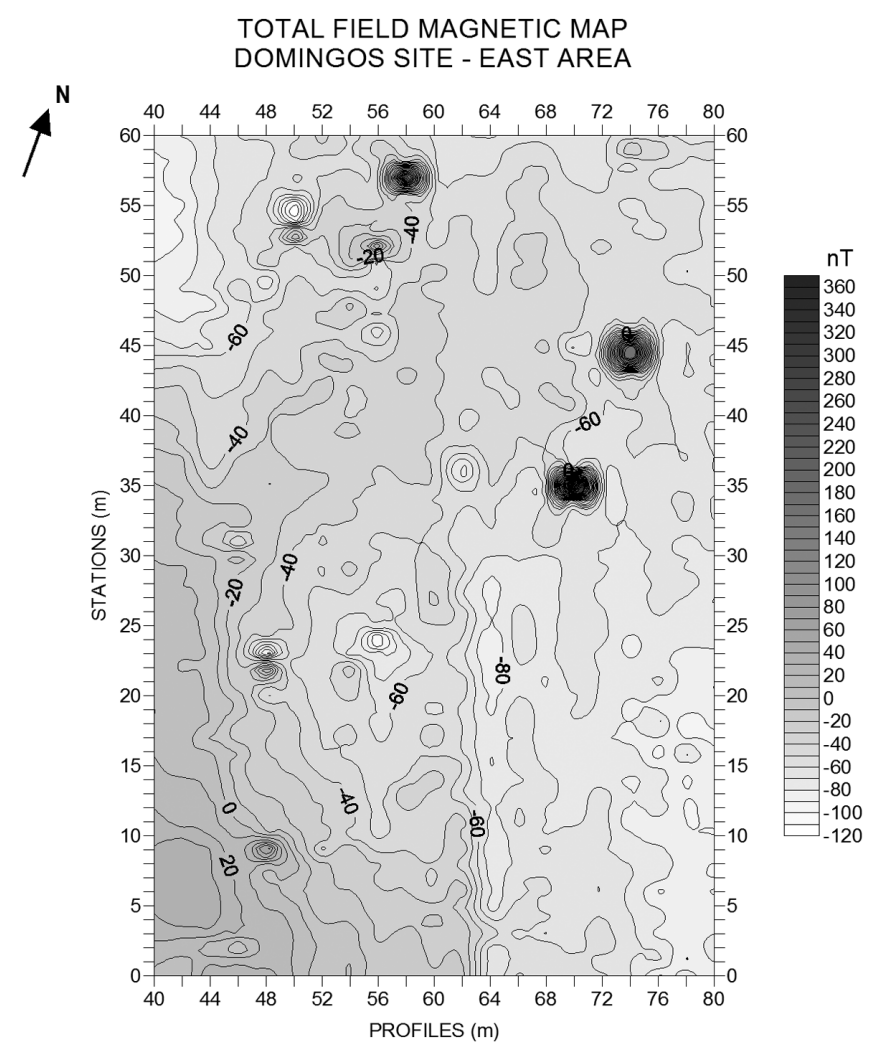

Figure 15 - Magnetic map of the eastern half of the area. The values are relative to the value $25,845 \mathrm{nT}$ measured in station 30 of profile 40 .

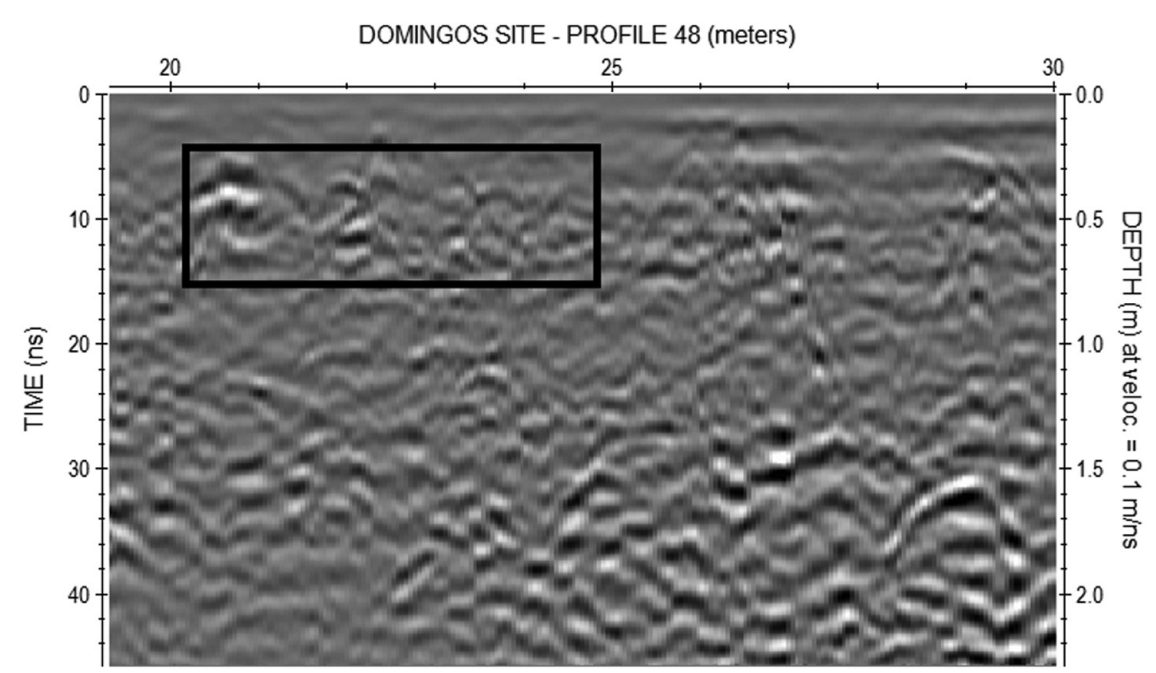

Figure 16 - Radargram obtained for part of profile 48, where a magnetic anomaly was detected and recommended for excavation.

\section{Archaeological excavations in the eastern portion of the study area}

Several anomalies found in the geophysical survey were not excavated; some of them contained ceramic material, while others revealed nothing.
Near the anomalies in profile 48 (stations 22 to 23) and profile 54 (station 22), several $1 \mathrm{~m} \times 1 \mathrm{~m}$ units were studied in excavation 37. Four burial urns were found in a line between profiles 48 and 50 (stations 23 to 24), and a burial urn and polished ax blade were found between profiles 52 and 54 (stations 


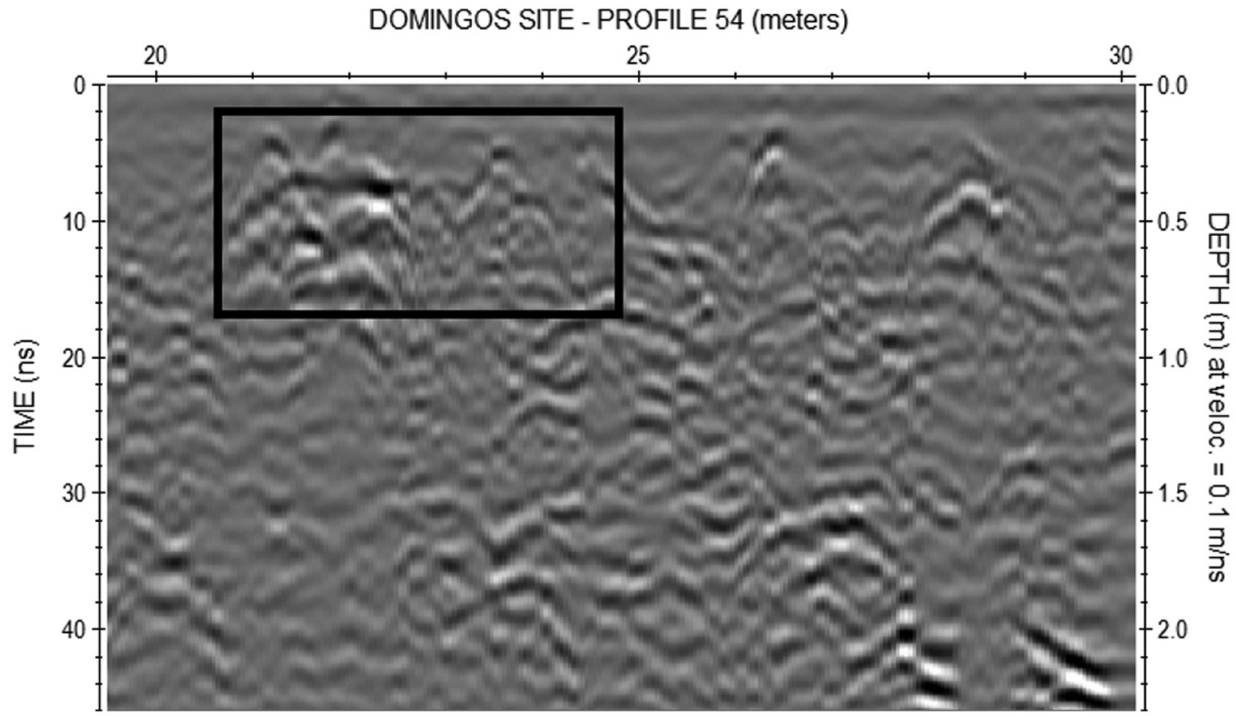

Figure 17 - Radargram obtained for part of profile 54, where a magnetic anomaly was detected and recommended for excavation.

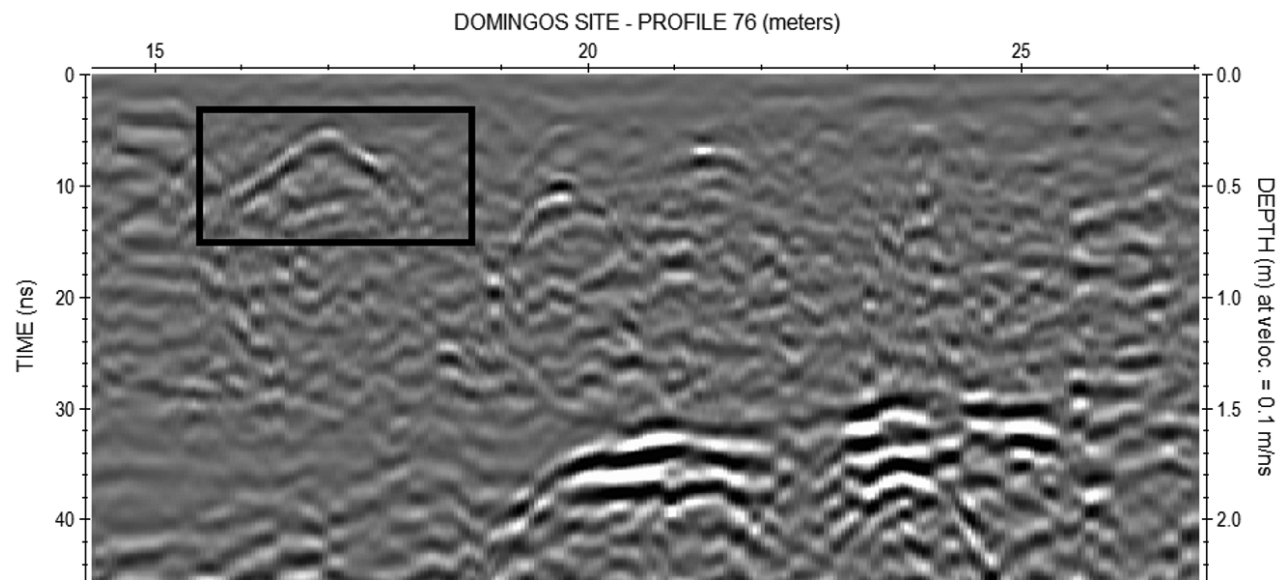

Figure 18 - Radargram obtained for part of profile 76, where a magnetic anomaly was detected and recommended for excavation.

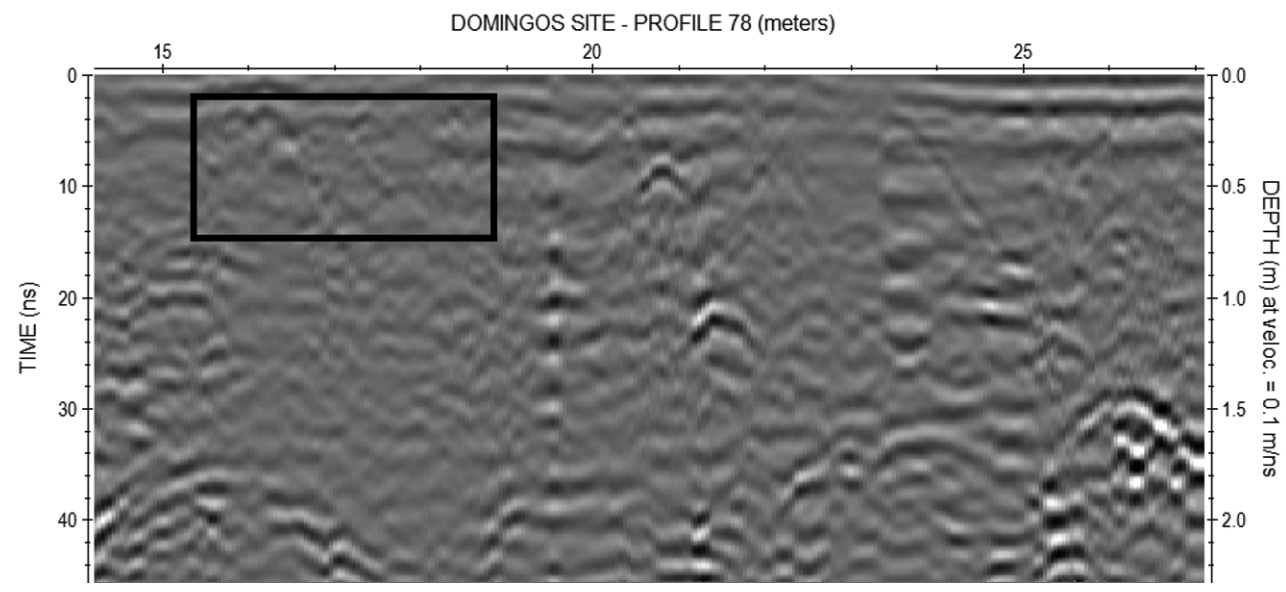

Figure 19 - Radargram obtained for part of profile 78 , where a magnetic anomaly was detected and recommended for excavation. 


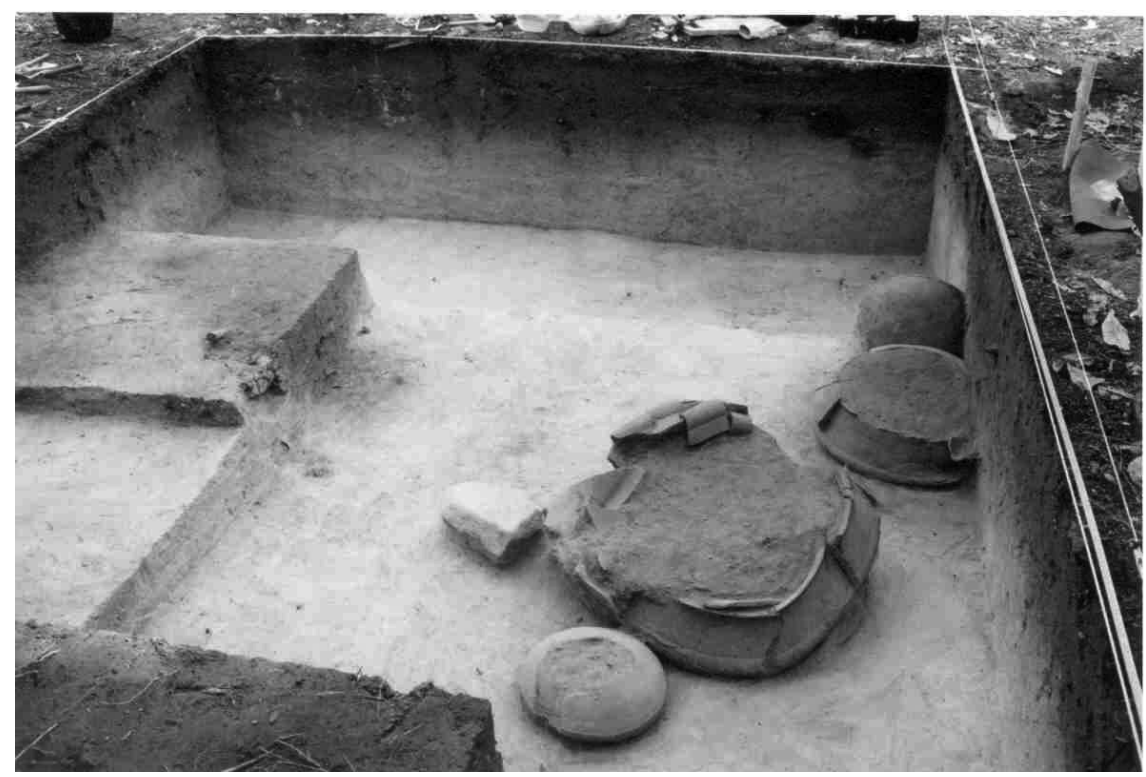

Figure 20 - Burial urns found between profiles 48 and 50 in excavation 37, conducted to test a geophysical anomaly detected in profile 48.

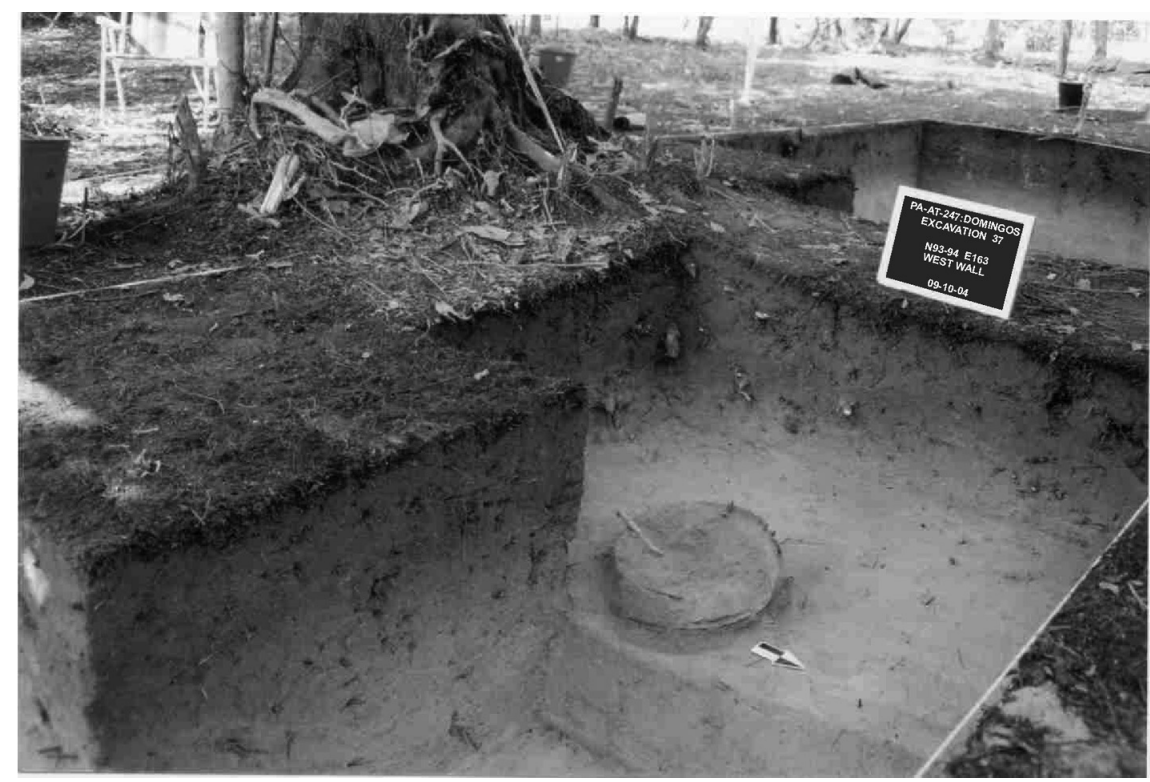

Figure 21 - Burial urn found between profiles 52 and 54 in excavation 37, conducted to test geophysical anomalies detected in profiles 54 and 56 .

23 to 25). Portions of this excavation are shown in Figures 20 and 21.

In the anomaly in profile 76 (stations 16 and 18), a unit from excavation 45 produced a burial urn between stations 15 and 16 and a large concentration of ceramic fragments between stations 16 and 17 (Fig. 22). The area of excavation 45 above the anomaly in profile 78 (stations 16 and 18) produced a polished blade between stations 15 and 16, as well as ceramic fragments (Fig. 23).

Charcoal collected in the excavation 46 was dated by Carbon-14 producing $770 \pm 40 \mathrm{AD}$.

The characteristics of the archaeological ceramics from Domingos Site, particularly in aspects related to its manufacturing, decoration, shape of containers and age allow to 


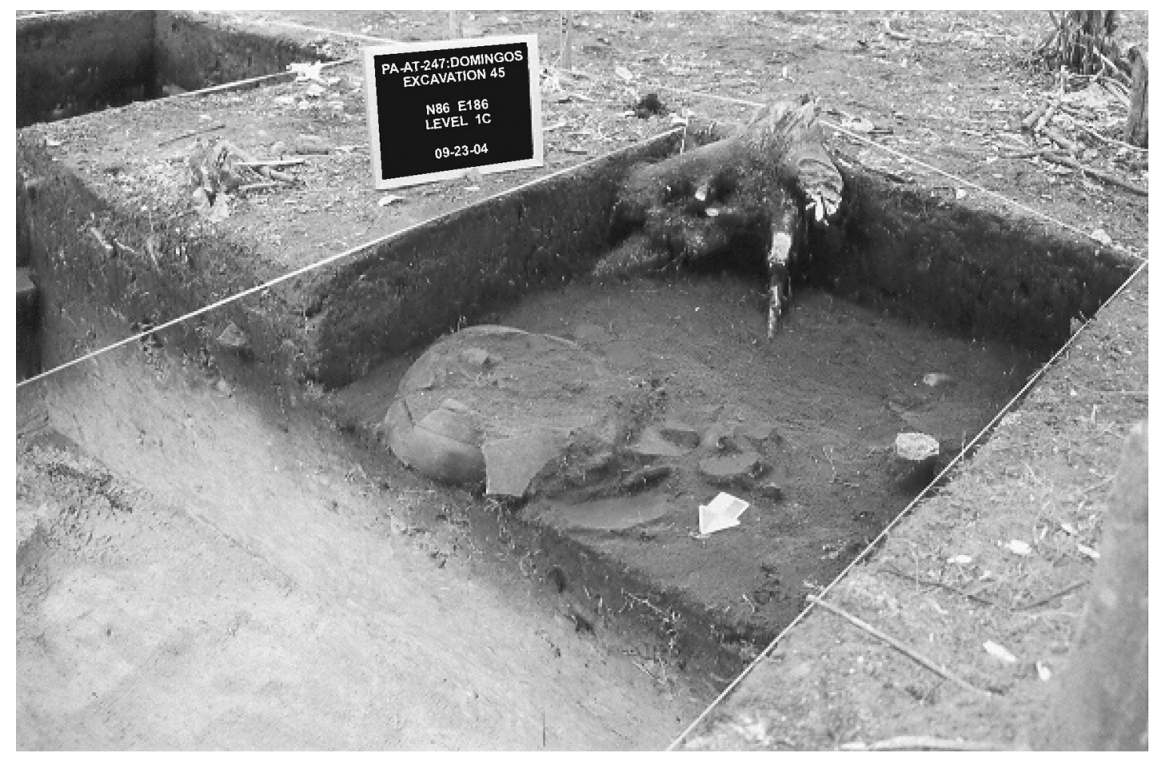

Figure 22 - Burial urn and ceramic fragments found in excavation 45, conducted to test a geophysical anomaly detected in profile 76.

consider it as belonging to the indigenous Tupiguarani potter tradition (Pereira et al., 2008).

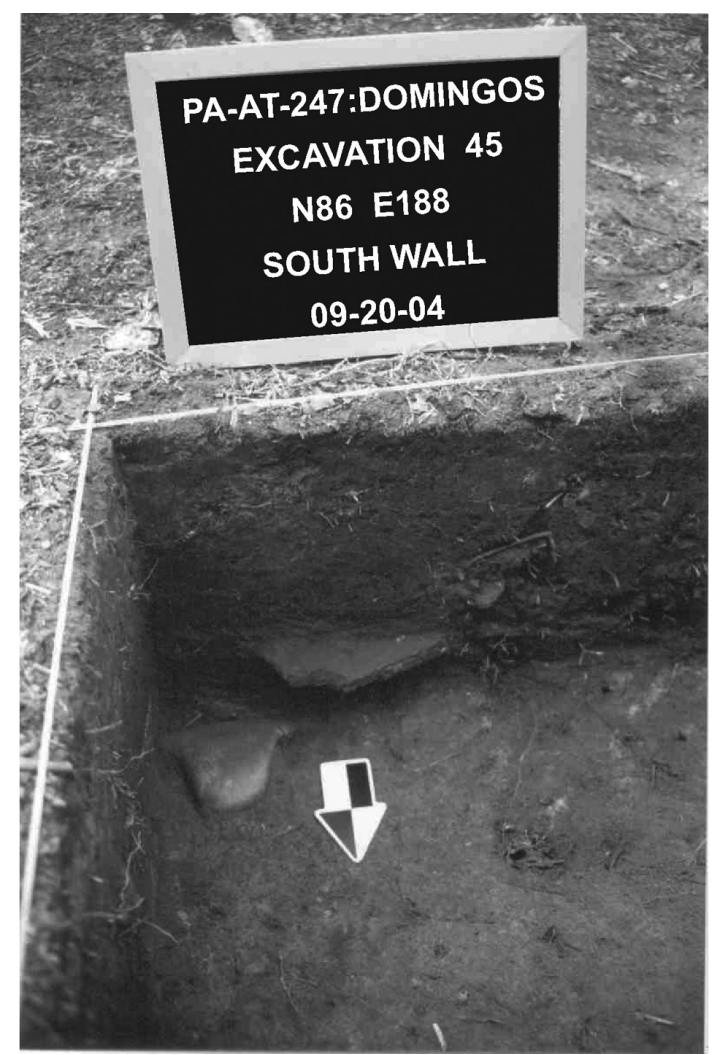

Figure 23 - Polished ax blade and ceramic fragment found in excavation 45 , conducted to test a geophysical anomaly detected in profile 78 .

\section{CONCLUSIONS}

Magnetic, electrical resistivity and GPR measurements performed on the site PA-AT-247: Domingos produced satisfactory results.

The magnetic measurements show several anomalies that were tested by archaeological excavation, which produced fragmented ceramic material, burial urns and ax blades. Carbon-14 and thermoluminescence dating of the archaeological material indicates that this site was occupied between the second and sixteenth centuries.

Excavation conducted at the location of strong magnetic anomalies in the southwestern corner of the study area showed that these anomalies were not caused by ceramics, but by blocks of mafic rocks rich in magnetic minerals (most likely magnetite). However, these rocks were mixed with a large amount of ceramic material and served as a guide for locating the ceramics.

The correlation between the resistivity models and the description of sediments found in the excavations caused the resistivity range of 2000 to $2500 \mathrm{ohm}-\mathrm{m}$ to be associated with the archaeological layer.

The GPR measurements show anomalous features that are characterized by lateral discontinuities and hyperbolic shapes. Some of these features are located over magnetic anomalies and were used as a guide for archaeological excavation in the eastern half of the study area.

The anomalous features GPR, obtained with the $400 \mathrm{MHz}$ antennas are inconclusive because it is difficult to associate them with the ceramic material. Some of these anomalous features were 
tested, confirming that they were caused by roots. Therefore, the method is not recommended as the primary method for archaeological prospection of the area. It is possible that a $900 \mathrm{MHz}$ antenna could produce better results.

\section{ACKNOWLEDGMENTS}

The research was conducted through a partnership between the Museu Paraense Emílio Goeldi, Companhia Vale and Sociedade Zeladora Amigos do Museu Emílio Goeldi. The authors thank the technicians Afonso Quaresma de Lima and Paulo Sergio Pereira Magalhães for their help during the field work.

\section{REFERENCES}

AITKEN MJ. 1974. Physics and archaeology, second edition. Clarendon Press, Oxford. $201 \mathrm{pp}$

ALVES JJA. 1979. Métodos geofísicos aplicados à arqueologia no estado do Pará [Geophysical methods applied to archaeology in the state of Pará]. Master thesis in Geophysics. Curso de Pós-Graduação em Ciências Geofísicas e Geológicas. Universidade Federal do Pará, 55 p.

ALVES JJA \& LOURENÇO JS. 1981. Métodos geofísicos aplicados à arqueologia no estado do Pará [Geophysical methods applied to archaeology in the state of Pará]. Boletim do Museu Paraense Emílio Goeldi, Série Geologia, 26: 1-52.

ARAGÃO RC, LUIZ JG \& LOPES PRC. 2010. Metodologia geofísica aplicada ao estudo arqueológico dos sítios Bittencourt e Jambuaçu, estado do Pará [Geophysical methodology applied to the study of the Jambuaçu and Bittencourt archaeological sites, state of Pará]. Revista Brasileira de Geofísica, 28(2): 249-263.

BARRADAS JA, SCHAAN DP \& LUIZ JG. 1999. Magnetic and GPR survey to identify archaeological features on Cacoal Site, Anajás River, Marajó Island, Pará, Brazil. Sixth International Congress, Brazilian Geophysical Society, Rio de Janeiro, Brazil, CD-ROM.

BEVAN BW \& RO0SEVELT AC. 2003. Geophysical exploration of Guajará, a prehistoric earth mound in Brazil. Geoarchaelogy, 18: 287-331.

COSTA ML \& KERN DC. 1999. Geochemical signatures of tropical soils with archaeological black earth in the Amazon, Brazil. Journal of Geochemical Exploration, 66: 369-385.

GLASER B \& WOODS WI (Eds.). 2004. Amazonian Dark Earths: Explorations in space and time. Springer, Berlin. $216 \mathrm{pp}$.

KERN DC \& KAMPF N. 1989. Antigos assentamentos indígenas na formação de solos com Terra Preta Arqueológica na Região de Oriximi- ná, Pará [The contribution of Indian prehistoric settlements to Archaeological Black Earth formation at Oriximiná-PA]. Revista Brasileira de Ciência do Solo, 13: 219-255.

KERN DC, D'AQUINO G, RODRIGUES T, FRAZÃO JJ, SOMBROEK W, MYERS T \& NEVES E. 2003. Distribution of amazonian dark earths in the Brazilian Amazon. In: LEHMANN J, KERN D, GLASERB \& WOODS W (Eds.). Amazonian Dark Earths: Origin, Properties, Management. Kluwer Academic Publishers, Dordrecht, 51-76p

LUIZ JG. 2010. Metodologias geofísicas aplicadas à prospecção arqueológica no estado do Pará [Geophysical methodologies applied to archaeological prospection in the state of Pará]. In: PEREIRA ES \& GUAPINDAIA VLC (Eds.). Arqueologia Amazônica [Amazonian Archaeology]. Belém, 2: $949-966 p$.

MAGALHÃES MP. 2001. Relatório de prospecção arqueológica na área da Mineração Serra do Sossego [Report on archaeological prospection in the mining area of Serra do Sossego]. Museu Paraense Emílio Goeldi, Belém, 32 pp.

PEREIRA E, SILVEIRA MI, RODRIGUES MCLF, COSTA CJCA \& MACHADO CL. 2008. A tradição Tupiguarani na Amazônia [The Amazonian Tupiguarani tradition]. In: PROUS A \& LIMA TA (Eds.). Os Ceramistas Tupiguarani [The Tupiguarani Potters]. Sigma, Belo Horizonte, 49-66 p

ROOSEVELT AC. 1991. Moundbuilders of the Amazon: Geophysical Archaeology on Marajo Island, Brazil. Academic Press, San Diego. 495 pp.

ROOSEVELTAC. 2007. Geophysical archaeology in the lower Amazon: a research strategy. In: WISEMAN J \& EL-BAZ F (Eds.). Remote Sensing in Archaeology. Springer, New York, 443-475p.

SCHAAN DP, KERN DC \& FRAZÃO FJL. 2009. An assessment of the cultural practices behind the formation (or not) of anthropogenic dark earth in Marajó Island archaeological sites. In: WOODS WI, TEIXEIRA WG, LEHMANN J, STEINER C, WINKLERPRINS AMGA \& REBELLATO L (Eds.). Amazonian Dark Earths: Wim Sombroek's Vision. Springer, Netherlands, $127-141 p$

SCHMIDT A. 2007. Archaeology, magnetic methods. In: GUBBINS D \& HERRER0-BERVERA E (Eds.). Encyclopedia of Geomagnetism and Paleomagnetism: 23-31 pp, Encyclopedia of Earth Sciences Series Heidelberg, Springer, New York.

WYNN JC. 1986a. Archaeological prospection: an introduction to the special issue. Geophysics, 51: 533-537.

WYNN JC. 1986b. A review of geophysical methods used in Archaeology. Geoarchaeology, 1: 245-257. 


\section{NOTES ABOUT THE AUTHORS}

José Gouvêa Luiz is bachelor in Geology from Universidade Federal do Pará, master in Geophysics from Universidade Federal da Bahia, and doctor in Geophysics from Universidade Federal do Pará. Currently he is retired professor of Universidade Federal do Pará, working in research. His research interest is the applied geophysics to mineral and groundwater prospection, to environment contamination, and to archaeology.

Edithe da Silva Pereira is bachelor in History from Universidade Federal do Pará (1982), master in History from Universidade Federal de Pernambuco (1990) and doctor in Geography and History from University of Valencia, Spain (1996). She is currently a researcher of Museu Paraense Emílio Goeldi and has productivity scholarship from CNPq. Has experience in the area of archeology, with emphasis on prehistoric archaeology, acting on the following topics: rupestrian art, prehistoric Amazonia, archaeological chart and archaeoturism. 